\title{
Augmented Reality sebagai Media Pendidikan Interaktif dalam Pandemi Covid-19
}

\author{
I Wayan Andis Indrawan ${ }^{1}$, Komang Oka Saputra ${ }^{2}$, Linawati ${ }^{3}$ \\ [Submission: 15-01-2021, Accepted: 27-08-2021]
}

\begin{abstract}
At the end of 2019 the pandemic spreads the first Covid-19 in Indonesia was found in February 2020 and finally massively spread to almost all provinces in Indonesia. The education sector is a sector that is quite affected by the Covid-19 pandemic, because in its application it involves a large number of times so that the teaching and learning process is transferred to Study from Home (SFH). Apart from video conferences in the world of education, there is no other potential technology that has been implemented and applied as a supporting medium for interactive education at various levels ranging from elementary schools, junior high schools, high schools and universities as well as other education such as Special Needs Schools, Kindergartens and Early childhood education programs. Augmented Reality appears as a digitalization of education in the application of interactive learning that can be a solution to this problem. This realization requires special attention, especially for areas in Indonesia that have not been touched by supporting infrastructure such as smartphones or laptops as media that support the use of Augmented Reality Technology. A potential learning mechanism that can be implemented is the independent learning method in the form of a Virtual Lab while studying at home (study from home). This media is quite exclusive and interactive and can still be developed in terms of content. This technology can be a fun learning media solution and can be learned from home as a form of realization of study from home in the current Covid-19 Pandemic.
\end{abstract}

Intisari - Pada akhir tahun 2019 pandemi Kembali merebak Covid-19 pertama di Indonesia ditemukan pada bulan Februari 2020 dan akhirnya secara masif menyebar hampir ke seluruh provinsi yang ada di Indonesia. Sektor Pendidikan merupakan sektor yang cukup terdampak oleh pandemi covid-19, karena dalam pengaplikasiannya melibatkan tingkat masa yang cukup banyak sehingga proses belajar mengajar dialihkan dengan Study from Home (SFH). Selain Video Conference dalam dunia Pendidikan belum ada teknologi potensial lain yang diimplementasikan serta diterapkan sebagai media pendukung Pendidikan interaktif di berbagai jenjang mulai dari Sekolah Dasar, Sekolah Menengah Pertama, Sekolah Menengah Atas dan juga

${ }^{1}$ Mahasiswa, Program Pasca Sarjana, Manajemen Sistem Informasi dan Komputer Fakultas Teknik Universitas Udayana, Jln. P.B. Sudirman, Denpasar, Bali 80232 (tlp:0361-239599; email: andisindrawan@gmail.com)

${ }^{2,3}$ Dosen, Program Pasca Sarjana, Magister Teknik Elektro Fakultas Teknik Universitas Udayana, Jln. P.B. Sudirman, Denpasar, Bali 80232 (tlp: 0361-239599; e-mail: 2okasaputra@unud.ac.id,3linawati@unud.ac.id)

Perguruan Tinggi pun juga Pendidikan lain seperti Sekolah I Wayan Andis Indrawan : Augmented Reality Sebagai Media...
Berkebutuhan Khusus, TK serta PAUD. Augmented Reality muncul sebagai skena digitalisasi pendidikan pada penerapan pembelajaran interaktif yang dapat menjadi solusi permasalahan ini. Realisasi ini membutuhkan atensi khusus terutama untuk daerah di Indonesia yang belum terjamah infrastruktur pendukung seperti smartphone atau Laptop sebagai media yang mendukung penggunaan Teknologi Augmented Reality. Mekanisme pembelajaran potensial yang dapat diimplementasikan adalah dengan metode pembelajaran mandiri dalam bentuk Virtual Lab selama belajar di rumah (study from home). Media ini cukup eksklusif dan interaktif dan masih bisa dikembangkan dari segi konten. Teknologi ini bisa menjadi solusi media pembelajaran yang menyenangkan dan dapat dipelajari dari rumah sebagai bentuk realisasi study from home dalam Pandemi Covid-19 yang sedang berlangsung saat ini.

Kata Kunci - Augmented Reality, Pendidikan, Media Pendidikan, Pandemi Covid-19

\section{PENDAHULUAN}

Pandemi merupakan suatu bencana atau wabah yang terjadi serta menyabar di wilayah yang luas serta menjangkiti beberapa atau bahkan hampir seluruh dunia [1]. Sejak awal abad ke 19 pandemi telah terjadi beberapa kali di dunia antara lain Black Death yang terjadi di London, flu spanyol, flu babi (disebabkan oleh virus H1N1), HIV/AIDs [2] [3] dan beberapa wabah lainnya. Pada akhir tahun 2019 pandemi Kembali merebak, kini adalah sebuah virus yang pertama kali mulai menyebar di Wuhan, China [4]. Virus ini dengan sangat cepat menjangkiti berbagai belahan dunia lain mulai dari Spanyol, Italia, Amerika bahkan Indonesia. Awal mula kasus covid-19 pertama di Indonesia ditemukan pada bulan Februari 2020 dan akhirnya secara masif menyebar hampir ke seluruh provinsi yang ada di Indonesia [5]. Hal ini akhirnya menyebabkan pemerintah untuk melakukan pembatasan-pembatasan aktivitas untuk mengurangi tingkat penyebaran virus corona. Pembatasanpembatasan yang dilakukan berupa pelarangan untuk bepergian keluar rumah jika tidak ada urgensi, physical distancing, bekerja dan belajar di rumah, penutupan bandara dan Pelabuhan serta dan lain lain. Bahkan kini dibeberapa daerah di Indonesia telah di terapkan PSBB (Pembatasan Sosial Berskala besar). Berbagai sektor industri pun terdampak seperti sektor pariwisata, perekonomian bahkan Pendidikan [5].

Sektor Pendidikan merupakan sektor yang cukup terdampak oleh status pandemi covid-19, karena dalam pengaplikasiannya melibatkan tingkat masa yang cukup banyak. Oleh karena itu pemberlakuan protap-protap

p-ISSN:1693 - 2951; e-ISSN: 2503-2372 
kesehatan pun juga dilakukan oleh instansi Pendidikan untuk membantu pemerintah meminimalisir tingkat penyebaran virus ini. Mulai dari pelarangan untuk melakukan perjalanan dinas bagi akademisi dan siswa, melakukan Study from Home (SFH), mempermudah birokrasi dengan memanfaatkan teknologi, berjemur di bawah sinar matahari, melakukan physical distancing, hingga minum vitamin untuk meningkatkan imunitas tubuh. Study from Home merupakan kunci penting untuk melanjutkan kelangsungan Pendidikan di Indonesia. Berbagai macam inovasi dilakukan instansi Pendidikan untuk memberikan kemudahan bagi tenaga pengajar dan siswa untuk melakukan interaksi proses belajar mengajar secara daring [6]. Beberapa teknologi yang dimanfaatkan antara lain Webex dan Zoom untuk melakukan teleconference atau belajar secara daring dalam satu kelas, kemudian e-learning yang digunakan untuk pemberian materi, penugasan, quiz bahkan hingga ujian.

Selain media-media tersebut kini instansi Pendidikan harus mampu kreatif dalam memanfaatkan teknologi yang memungkinkan untuk membantu proses belajar mengajar sehingga kurikulum yang dicanangkan mampu terpenuhi dan kualitas pembelajaran tetap tepat sasaran. Salah satu teknologi potensial yang bisa dimanfaatkan dalam situasi ini adalah Augmented Reality. Teknologi ini memiliki fungsi yaitu merekonstruksi informasi menjadi sebuah visualisasi digital yang dikombinasikan dengan dunia nyata, sehingga siswa menjadi mudah untuk membayangkan informasi yang disampaikan. Augmented Reality yang mendukung platform smartphone semakin memudahkan siapa saja dapat menggunakannya. Dari segi tata cara penggunaannya pun juga sangat mudah, user hanya perlu untuk melakukan scanning marker untuk mentrigger munculnya objek virtual yang ingin ditampilkan [9].

Augmented Reality dalam dunia Pendidikan belum diimplementasikan serta diterapkan sebagai media pendukung Pendidikan interaktif di berbagai jenjang mulai dari Sekolah Dasar, Sekolah Menengah Pertama, Sekolah Menengah Atas dan juga Perguruan Tinggi. Teknologi ini sebenarnya sudah memunculkan ide-ide untuk melahirkan media-media edukasi mengenai berbagai bidang ilmu, namun belum ada instansi Pendidikan yang menerapkan sebagai media wajib yang berfungsi menjadi sarana pembelajaran lebih-lebih di Masa Pandemi Covid 19 ini. Teknologi ini memiliki potensi untuk mendukung pembelajaran study from home maupun pembelajaran dikelas. Namun jika menilik luasnya wilayah Indonesia, salah satu infrastruktur pendukung Augmented Reality yaitu smartphone tentu akan menjadi kendala karena tidak semua siswa di wilayah Indonesia memiliki smartphone. Perlu dipertimbangkan mekanisme atau skema perencanaan pemenuhan infrastruktur jika teknologi ini akan diterapkan di luasan wilayah Indonesia secara merata. Tidak hanya Pendidikan formal, namun juga sekolah berkebutuhan khusus (bisu, tuli, autis, cacat fisik dan lain sebagainya) patut menjadi perhatian karena juga turut terdampak pandemi. Pendidikan berkebutuhan khusus membutuhkan peranan ekstra dari orang tua dan guru jika nanti penerapan teknologi Augmented Reality juga diterapkan untuk skena ini. Ada banyak hal entitas-entitas yang perlu menjadi perhatian dalam digitalisasi Pendidikan. Jika pembelajaran didalam kelas bisa diakomodir dengan video conference, namun tidak dengan laboratorium. Laboratorium membutuhkan teknologi yang mampu memuat entitasentitas laboratorium dan pengimplementasiannya secara virtual tanpa mengurangi tujuan didalamnya. Salah satu teknologi yang memungkinkan untuk merealisasikan ide ini adalah Augmented Reality, dimana skema kedepan bisa dimuat dalam bentuk Virtual Laboratorium.

Lingkup Pendidikan yang cukup luas juga harus mencakup tingkat Pendidikan dini seperti PAUD dan Taman Kanak-Kanak. Entitas ini juga patut menjadi perhatian karena merupakan tingkatan pembelajaran dasar yang paling dini dan akan menjadi landasan pengetahuan dari para calon siswa sebelum mereka masuk ke tingkatan sekolah formal. Augmented Reality tentu akan menjadi teknologi yang sangat menyenangkan bagi anak-anak karena lebih mengedepankan visual yang dapat menarik perhatian anak-anak. Realisasi ini juga membutuhkan perhatian ekstra dari guru dan orang tuan untuk pengimplementasiannya salah satunya yaitu infrastruktur pendukung seperti smartphone dan pengalokasian waktu jam belajar untuk menghindari efek dari radiasi layar smarphone yang berdampak bagi siswa. Dalam kurun waktu beberapa tahun terakhir Augmented Reality telah melahirkan berbagai macam produk edukasi, namun belum difungsikan nyata untuk mendukung proses pembelajaran atau media Pendidikan interaktif bagi dunia Pendidikan [7] [8]. Dengan fitur-fitur mumpuni dari Augmented Reality, jurnal ini akan mengkaji bidang-bidang Pendidikan yang dapat dimanfaatkan sebagai media Pendidikan bagi siswa guna membantu penerapan physical distancing dan Study from Home serta mengulas mengenai skema ide dan gagasan penerapan Augmented Reality ini di dunia Pendidikan Indonesia dalam upaya pemerintah untuk menanggulangi wabah Pandemi Covid-19 [5].

\section{STUDI LITERATUR}

Studi literatur pada jurnal ini mengacu ke beberapa poin antara lain latar belakang masalah, Minat siswa untuk belajar dirumah, Problematika tingkat penalaran siswa, serta teknologi potensial untuk visualisasi konsep abstrak.

\section{A. Latar Belakang Masalah}

Dengan status pandemi wabah covid-19 ini berbagai sektoral mulai menemui permasalahan-permasalahan yang harus dihadapi dengan segala keterbatasan. Sektor Pendidikan yang mengharuskan tenaga pendidik dan siswa untuk melakukan proses belajar mengajar dari rumah harus memutar otak untuk tetap menjaga kualitas pembelajaran yang ingin dicapai. Teknologi eksisting pada realisanya bermodalkan keunggulan serta kelemahan sehingga harus di optimalkan dengan pendekatan-pendekatan yang lebih ekstra agar siswa mau belajar dirumah [10]. Dalam realisasinya pembelajaran daring telah memanfaatkan teknologi-tekologi video conference seperti halnya Webex Cisco, Zoom dan Google Meets. Namun apabila metode pembelajaran dengan menggunakan media teleconference 
seperti itu saja, tentu dirasa akan membosankan belum lagi masa pandemi yang masih belum kunjung menemukan titik terang, tentu media pembelajaran interaktif sangat dibutuhkan dengan mengelaborasi berbagai macam jenis teknologi yang menyenangkan untuk dipelajari dan tidak membuat bosan seperti halnya seminar virtual yang mempelajari bidang ilmu hanya dari presentasi dan penjelasan dari narasumber. Walaupun dapat di sisipkan video-video yang menarik dan dapat meningkatkan minat para siswa, tidak banyak yang memilih mematikan kamera dan suara mereka untuk tidak menonton atau mendengar seminar dan memilih mengambil kegiatan lain yang bisa mereka lakukan, sehingga pembelajaran menjadi tidak terfokus dan cenderung tidak efektif.

Selain peran orang tua, peran teknologi yang dimanfaatkan untuk belajar dirumah memegang peranan penting. Belajar dirumah tentu akan mengurangi tingkat konsentrasi belajar siswa sehingga akan menimbulkan permasalahan-permasalahan seperti malas untuk belajar, keterbatasan partner diskusi jika menemui masalah dalam menerima materi, konsentrasi terpecah akibat suasana rumah yang tidak kondusif dan masih banyak lainnya. Karena karakter siswa adalah berbeda-beda, aada yang cepat mengatur focus apabila belajar dirumah, ada juga yang sangat berat untuk menerima pembelajaran apabila dilakukan dirumah karena suasana yang tidak mendukung untuk focus belajar dan cenderung lebih asik dengan aktifitas di rumah sehingga terjadi tunda menunda dalam minatan untuk belajar. Begitu juga rekan sosialisasi yang minim juga menjadi kendala, rekan kelompok yang mereka sering temui di sekolah untuk berdiskusi perhal tugas, berdiskusi perihal soal-soal, berdiskusi perhial kegiatan ekstrakulikuler dan lain sebagainya akan cenderung menimbulkan kebosanan karena mayoritas kegiatan pembelajaran dari dikerjakan dirumah dan sendiri. Oleh karena itu dibutuhkan suatu teknologi yang menarik sehingga mampu mengalihkan focus siswa untuk belajar semakin meningkat sehingga menutupi keterbatasanketerbatasan selama belajar di rumah. Sebuah teknologi yang mampu meningkatkan minat, menumbuhkan rasa penasaran, mudah dalam mencerna materi serta tidak menimbulkan rasa kebosanan akan minimnya kegiatan social yang biasa dilakukan Bersama-sama namun kini harus dilakukan sendiri atau hanya dengan orang-orang terdekat saja. Teknologi yang memungkinkan mencakup hal-hal tersebut salah satunya Augmented Reality [11].

\section{B. Minat Siswa Belajar di Rumah}

Study from Home yang diterapkan selama ini tentunya tidak akan sepenuhnya menemui keberhasilkan. Tingkat pendidikan siswa yang bervariasi mulai dari siswa Pendidikan Taman Kanak-Kanak, Sekolah Dasar, Sekolah Menengah Pertama, Sekolah Menengah Atas/Umum dan Dunia Perkuliahan tentunya akan menghasilkan minat yang berbeda-beda. Siswa TK dan SD tentu akan membutuhkan

I Wayan Andis Indrawan : Augmented Reality Sebagai Media... bantuan ekstra dari orang tua untuk membantu peran guru dalam memberikan pembelajaran bagi buah hatinya. Berbeda dengan SMP, SMA dan Perguruan Tinggi yang mungkin sedikit lebih bisa menjaga stablitas minat belajar mereka selama dirumah. Minat belajar dirumah harus dijaga agar siswa bisa mencerna pembelajaran dengan baik [12]. Untuk meningkatkan minat belajar siswa selama berada dirumah, tentu membutuhkan atensi di beberapa aspek salah satunya penjadwalan yang baik, penugasan yang konstruktif, pembelajaran yang tidak membosankan dan juga peranan anggota keluarga dalam menjaga kondusifitas siswa dalam belajar dirumah. Karena jika menyepelekan hal-hal tersebut dengan hal-hal lain seperti main games, menonton TV, tidur dan kegiatan-kegiatan lain yang lebih menarik. Maka dari itu dari segi materi pembelajaran juga sebisa mungkin dibuat menarik sehingga minat belajar siswa di rumah semakin meningkat. Penelitian sebelumnya menyatakan bahwa minat belajar siswa akan menurun apabila terlalu banyak melibatkan konsep abstrak sehingga membuat siswa akan menjadi bosan.

\section{Problematika Tingkat Penalaran Siswa}

Dalam pembelajaran di kelas secara tatap muka penalaran dari masing-masing peserta pembelajaran tentunya berbeda-beda, dimana ada yang mudah paham dengan satu kali penjelasan, namun ada juga yang membutuhkan penjelasan berkali kali untuk memahami pembelajaran tersebut [13]. Heterogenitas tersebut merupakan hal yang wajar dan harus membutuhkan peranan dari tenaga pendidik untuk menghadapi hal tersebut. Apalagi di dalam kondisi yang sedang menghadapi pandemi yang mengharuskan untuk belajar menggunakan teknologi daring. Tenaga pendidik harus jeli dalam memanfaatkan teknologi untuk menjelaskan materi ke siswa agar mudah dicerna. Dalam penelitian sebelumnya disebutkan bahwa siswa akan lebih mudah menelaah atau menerima materi dengan visualisasi ketimbang materi dengan konsep abstrak. Selain meningkatkan tingkat penalaran, materi visual juga akan meningkatkan minat belajar siswa [14].

\section{Teknologi Potensial Untuk Visualisasi Konsep Abstrak}

Meningkatkan minat belajar siswa dengan merekonstruksi konsep abstrak menjadi bentuk visual akan membantu tenaga pendidik dalam penyampaian materi. Dalam masa Study from Home yang sedang berlangsung, dibutuhkan teknologi sebagai media edukasi yang mampu untuk membantu meningkatkan minat siswa dalam belajar. Salah satu teknologi yang mampu merealisasikan hal tersebut adalah Augmented Reality [15]. Augmented Reality memiliki fitur untuk merubah informasi menjadi bentuk visual. Sehingga dengan memanfaatkan teknologi ini, siswa akan menerima pembelajaran dalam bentuk p-ISSN:1693 - 2951; e-ISSN: 2503-2372

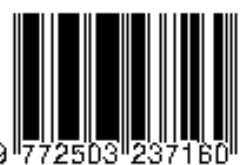


visual yang mudah dipahami. Augmented Reality adalah aplikasi yang mampu menampilkan benda kecil besar, cepat, lambat dapat dilihat dengan mata telanjang secara jelas tanpa bantuan [16]. Seperti halnya penelitian mengenai Augmented Reality yang merepresentasikan Gedung Musem baik di Karangasem dan Tabanan [17], teknologi ini mampu menampilkan benda-benda museum dari kecil hingga besar dengan merekonstruksi objek museum ke dalam bentuk objek 3 dimensi. Dalam aplikasi ini, pengunjung bisa mempelajari sejarah dan melihat isi dari museum secara virtual dan berinteraksi dengan objek tersebut. Begitu juga Aplikasi AR Molymod senyawa hidrokarbon yang merupakan media pembelajaran mata pelajaran kimia [18]. Aplikasi ini terkandung senyawa turunan alkana seperti alkil, alkohol dan alkanol. Sejumlah 206 objek dan 30 reaksi adisi terpampang secara jelas dan detail dalam aplikasi ini, agar siswa tidak salah tanggap dalam membedakan senyawa-senyawa yang ada. Selanjutnya adalah aplikasi AR yang diterapkan untuk pembelajaran biologi adalah Aplikasi AR Sistem pencernaan. Aplikasi ini mampu memvisualisasikan organorgan pencernaan manusia ke dalam objek 3 dimensi. Dengan kelebihan ini tentunya untuk mempelajari organ pencernaan tenaga pengajar dan siswa tidak harus mempraktekannya secara langsung, cukup dengan penggambaran secara virtual dengan aplikasi augmented reality [7].

Secara harfiah teknologi Augmented Reality dapat di definisikan sebagai platform yang dapat mengkombinasikan benda virtual ke dalam dunia nyata sebagaimana kedua objek ini terlihat menyatu satu sama lain. Augmented reality tidak sama dengan virtual reality, karena secara definisi virtual reality merupakan dunia virtual yang dibuat meneyerupai dunia nyata. Augmented Reality memiliki beberapa kelebihan jika dibandingkan virtual reality. Augmented Reality memanipulasi dunia nyata pada layar perangkat menggunakan kamera atau perangkat pengambil gambar lainnya pada smartphone sedangkan Virtual Reality memanfaatkan sensor dan periperal lain dan membuat penggunanya merasa di dunia lain yang benar-benar tergambar secara virtual. Disatu sisi memang Augmented Reality lebih terkenal diawal ketimbang Virtual Reality dan Augmented Reality kini sudah siap pakai dan Virtual Reality masih dikembangkan dengan peningkatan dengan program dan berbagai macam perangkat keras. Kesamaan dari keduanya adalah Augmented Reality dan Virtual Reality sama-sama menghasilkan konten virtual yang mana pengguna dapat berinteraksi dengan keduanya dengan berbagai macam cara dan fitur. Augmented Reality keduanya memiliki area pengembangan yang notabene sama yaitu untuk pengembangan dunia pendidikan dan edukasi, bidang kesehatan, hiburan, media dan lain sebagainya. Dari segi harga keduanya juga sama-sama bervariasi mulai dari gratis hingga mahal namun dilengkapi dengan banyak fitur.

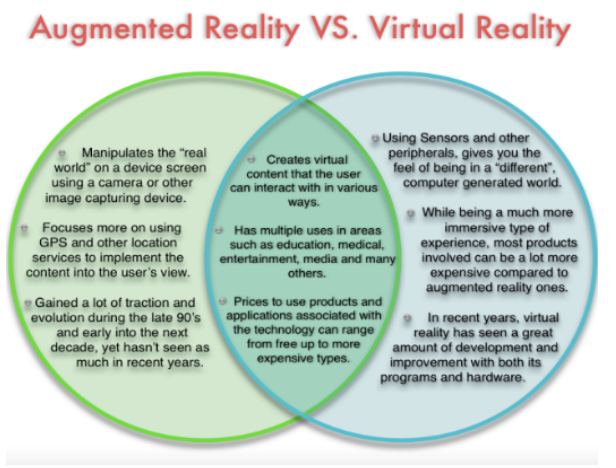

Gambar 1 : Perbedaan Augmented Reality dengan Virtual Reality

Augmented reality mampu memberikan gambaran secara live antara dunia nyata dan dunia virtual [11]. Augmented reality juga bisa menampilkan visualisasi secara rinci suatu objek yangmana seharusnya tidak bisa dilihat dengan mata telanjang seperti halnya unsur kimia berupa atom [19]. Augmented Reality memiliki keunggulan sebagai medua edukasi yang dibarengi dengan respon positif bahwasannya teknologi ini memberikan pengaruh yang cukup besar dimana siswa yang mempelajari materi gelombang akan lebih mudah mengerti menggukanan teknologi ini ketimbang tidak menggunakan teknologi augmented reality yang dapat dilihat dari hasil komparasi serta analisa terhadap pembelajaran dua jenis siswa tersebut. [20]. Augmented Reality dinilai layak jika di implementasikan dalam Media pembelajaran seperti penelitian mengenai penggunaan aplikasi augmented reality untuk mata pelajaran elektronika yangmana dari total skor terbanyak yaitu 100, mendapatkan skor sebanyak 87 sehingga dapat di golongkan memadai. di implementasikan sebagai media pembelajaran [16]. Jika menilik dari keunggulankeunggulan Augmented Reality diatas tentu platform ini sangat bermanfaat dalam meningkatkan minat siswa dalam pembelajaran. Mulai dari pengilustrasian benda yang tidak terlihat yang jika di dunia Pendidikan eksisting tentunya akan menimbulkan perbedaan konsepsi dari masingmasing siswa karena tiap-tiang orang pasti memiliki tingkat penalaran yang berbeda-beda. Pembelajaran tatap muka memang bisa sedikit dibantu dengan metoda contoh gambar 2 dimensi pada papan tulis, namun ini tentu masih akan menyulitkan siswa karena tingkat guru dalam merepresentasikan suatu gambaran tidak selalu sama, bahkan untuk merepresentasikan objek 3 dimensi kedalam papan 2 dimensi. Augmented Reality seperti penelitian yang telah dibahas sebelumnya bisa menjadi solusi terbaik dalam pemecahan masalah ini, pun juga bisa dipelajari dimana saja baik di sekolah maupun dirumah, apalagi di dalam kondisi pandemic seperti ini. AR juga bisa menjadi solusi pembelajaran biologi yang pada realisasinya sangat sulit untuk dibayangkan. Bagaimana siswa bisa memahami bentuk dari organ-organ dalam tubuh manusia yang sejatinya belum pernah dilihat sebelumnya, mulai dari paru-paru, jantung, pancreas, usus, otak dan lain-lain. Dalam Pendidikan tatap muka memang hal ini bisa digambarkan dengan ilustrasi patung manusia yang memperlihatkan organ dalam, namun siswa tentu tidak dapat melihat proses-proses yang terjadi didalamnya, 
bagaimana paru-paru memompa darah keseluruh tubuh, bagaimasa proses ekskresi dan sekresi manusia, lalu manusia bernafas dan lain-lain tentu tidak bisa dibayangkan. ARbisa menjadi solusi dan dapat merealisasikan semua hal tersebut dalam bentuk animasi 3D yang akan menggambarkan hal tersebut dalam sebuah wadah media edukasi interaktif yang bisa di interaksikan dengan cara perbesar objek, rotasi, memutar animasi dan lain sebagainya. Sehingga siswa tidak kesulitan membayangkan bagaimana proses-proses biologi terjadi pada tubuh manusia, yang kedepan juga bisa di terapkan untuk mempelajari anatomi serta organ tubuh dari hewan maupun tumbuhan. Kelebihan-kelebihan dari AR sangat berbanding lurus dengan kebutuhan media pembelajaran yang dapat mempermudah siswa belajar berbagai macam hal dari visualisasi 3 Dimensi. Muara dari kelebihan AR sebagai media pendidikan ini adalah mendorong siswa berfikir lebih kreatif, kritis sehingga meningkatkan pengalaman dan wawasan siswa itu sendiri [21]. Pada Tabel 1 menampilkan beberapa dari keunggulankeunggulan AR dalam dunia pendidikan yang di sorot dalam literatur. Banyak sekali keuntungan jika mengintegrasikan teknologi $\mathrm{AR}$ ke dalam proses pembelajaran. Keunggulan pada tabel adalah keunggulan yang paling umum dan lumrah ditemui.

TABEL I

KEUNTUNGAN MENGGUNAKAN AR DALAM PENDIDIKAN

\begin{tabular}{|l|l|}
\hline Penulis & Kelebihan \\
\hline Yostab M. et al. (2014) & $\begin{array}{l}\text { Memungkinkan interaksi antara dunia } \\
\text { nyata dan dunia virtual serta mampu } \\
\text { memanipulasi objek. }\end{array}$ \\
\hline $\begin{array}{l}\text { C. Althea, S. Lahallo, A. } \\
\text { Wiranatha, and I. G. M. M. } \\
\text { Arya (2016) }\end{array}$ & $\begin{array}{l}\text { Mendukung tenaga pengajar dengan } \\
\text { menambah alat peraga berupa AR untuk } \\
\text { merekonstruksi objek nyata yang tidak } \\
\text { bisa lihat dengan mata telanjang. }\end{array}$ \\
\hline $\begin{array}{l}\text { R. Mauludin et al. (2017) } \\
\text { Memungkinkan visualisasi objek yang } \\
\text { susah untuk di lihat seperti organ tubuh } \\
\text { manusia dan objek-objek sejenis. }\end{array}$ \\
\hline $\begin{array}{l}\text { Wahya Dhiyatmika et al. } \\
\text { (2016) }\end{array}$ & $\begin{array}{l}\text { Pengalaman belajar yang tidak terikat } \\
\text { dengan jam pelajaran ataupun di ruang } \\
\text { kelas, siswa bisa mempelajarinya } \\
\text { dimana saja dan kapan saja. }\end{array}$ \\
\hline
\end{tabular}

Pada tabel I diatas dijelaskan beberapa penelitian yang sudah pernah dilakukan memanfaatkan teknologi AR. Dimana dijelaskan AR merupakan sebuah teknologi revolusioner yang memungkinkan siswa berinteraksi dengan benda visual yang seolah-olah menyatu dengan dunia nyata sehingga interaksi tersebut bisa terlihat secara realistis. Objek visual yang diajak berinteraksi tersebut bisa dimanipulasi agar terlihat menyatu dengan dunia nyata. Penelitian ini menjelaskan bagaimana penggunanya dapat berinteraksi dengan alat music berbentuk visual yang apabila disentuh akan memberi trigger untuk mengeluarkan suara khas dari alat music tersebut. Sehingga pengguna dapat mempelajari alat music tersebut walaupun tidak

I Wayan Andis Indrawan : Augmented Reality Sebagai Media... memilikinya dan cukup hanya menggunakan teknologi AR ini saja [22].

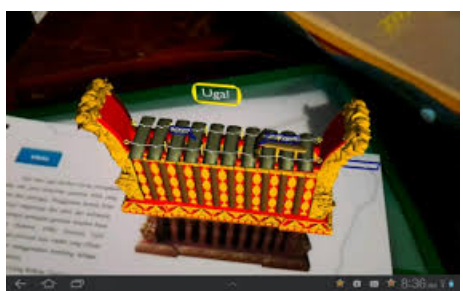

Gambar 2: AR Book Pengenalan Perangkat Gamelan Bali

Begitu juga teknologi ini dapat mengilustrasikan bendabenda yang tidak dapat bisa dilihat dengan mata telanjang, sehingga mempermudah pengajar untuk memanfaatkan alat peraga dalam kemasan AR yang sebagaimana pembelajaran tatap muda siswa mayoritas hanya akan menghafal jenis-jenis senyawa dan agak sulit membedakan satu sama lain karena tidak ada alat bantu visual untuk menjadi pembeda yang memudahkan siswa untuk mempelajarai dan memahami materi tersebut. [18].

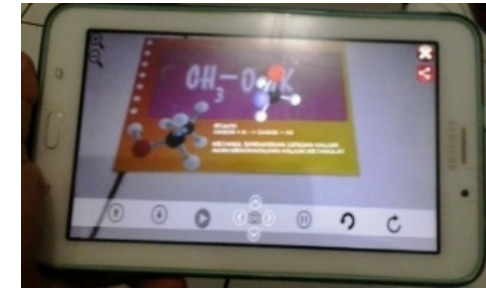

Gambar 3 : Media Pembelajaran Molymod Senyawa Hidrokarbon Teknologi Augmented Reality

Selain itu AR seperti yang sudah dijelaskan sebelumnya dapat digunakan sebagai media pembelajaran visualisasi objek-objek yang susah untuk di visualisasikan seperti anatomi tubuh manusia atau organ dalam mahluk hidup yang dalam prakteknya biasanya menggunakan ilustrasi patung yang tidak bisa digunakan untuk melihat proses yang ada didalamnya baik dalam skala besar ataupun skala kecil sekecil-kecilnya seperti ilustrasi pori-pori kulit manusia, sel-sel yang terdapat dalam tubuh manusia, bagaimana proses sistem pencernaan mulai dari proses awal hingga akhir [23].

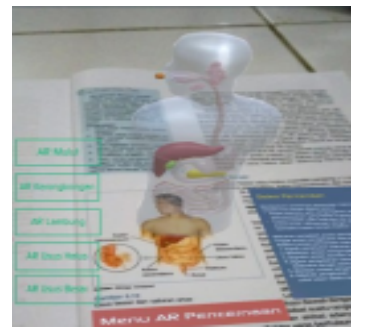

Gambar 4 : Augmented Reality Sebagai Media Pembelajaran Sistem Pencernaan pada Manusia dalam Mata Pelajaran Biologi

Terakhir, Augmented Reality dijelaskan pada tabel dapat menghasikan pengalaman belajar yang dapat dilakukan diluar jam pelajaran serta dapat dilakukan dimana saja dan kapan saja. Penelitian ini membuktikan bahwasannya

p-ISSN:1693 - 2951; e-ISSN: 2503-2372

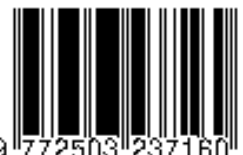


Augmented Reality adalah teknologi interaktif yang sangat menarik untuk digunakan dan dapat meningkatkan minat para penggunanya. Penelitian ini mengambil sampel pembelajaran mengenai pembelajaran jenis-jenis binatang yang tentunya akan menarik minat bagi anak-anak karena kemasannya tentu akan lebih menarik yang di sediakan dalam bentuk visual dan beranimasi, seolah-olah anak tersebut melihat binatang itu secara langsung dan mempelajari bagaimana bentuk perbedaan setiap binatang, bagaimana warna dari binatang tersebut, jumlah bagian tubug dari binatang bahkan suara dari binatang tersebut, sehingga anak-anak tidak saja menggunakan smartphone mereka untuk bermain, namun juga belajar sambil bermain walaupun itu tidak di sekolah [24].

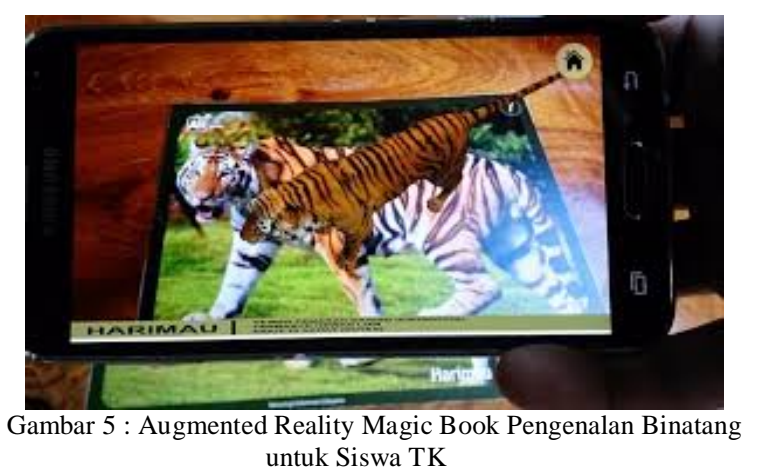

\section{Metodologi PenElitian}

Bab ini memaparkan tentang penerapan serta kontribusi teknologi Augmented Reality di beberapa bidang pendidikan. Adapun beberapa mata pelajaran atau bidang pendidikan yang memungkinkan untuk menggunakan teknologi Augmented Reality adalah Fisika, Kimia, Biologi, Matematika, Sejarah, Astronomi, serta Agama [25] [26]. Penelitian tentang penerapan AR di bidang ini ditinjau untuk mengevaluasi potensi AR dalam media pendidikan. Tabel 2 merangkum penelitian yang dilakukan pada AR di berbagai bidang pendidikan. Analisis mencakup contoh bagaimana AR diterapkan di masing-masing bidang.

Tujuan dari kajian ini adalah untuk melakukan identifikasi potensi-potensi dari aplikasi Augmented Reality di dunia pendidikan. Adapun penelitian-penelitian ini dipilih dengan kategori kurun waktu dari tahun 2007 hingga tahun 2019, dimana pada tahun 2007 adalah awal mula perkembangan teknologi Augmented Reality. Selanjutnya, studi harus mewakili bidang-bidang yang berbeda untuk merepresentasikan bahwa AR telah digunakan di berbagai bidang. Terakhir, teknologi AR yang dipilih harus menunjukkan serta menyoroti tujuan dan fitur teknologi AR yang telah digunakan. Hasilnya disajikan dalam Tabel 2.

TABEL III

PENERAPAN AR Di BERBAGAi BIDANG PENDIDIKAN

\begin{tabular}{|c|c|c|c|}
\hline Penulis & Bidang & Tujuan & Fitur AR \\
\hline $\begin{array}{l}\text { C. A. Sugianto } \\
\text { (2018) }\end{array}$ & $\begin{array}{l}\text { Astronomi } \\
\text { (Tata Surya) }\end{array}$ & $\begin{array}{l}\text { Menampilkan } \\
\text { visualisasii benda- }\end{array}$ & $\begin{array}{l}\text { Pemodelan } \\
\text { Planet }\end{array}$ \\
\hline
\end{tabular}

\begin{tabular}{|c|c|c|c|}
\hline & & benda tata surya & \\
\hline $\begin{array}{l}\text { Andis, } \\
\text { Bayupati dan } \\
\text { Putri (2017) }\end{array}$ & $\begin{array}{l}\text { Agama } \\
\text { Hindu } \\
\text { (Dewata } \\
\text { Nawa } \\
\text { Sanga) }\end{array}$ & $\begin{array}{l}\text { Memvisualisasikan } \\
\text { posisi Dewata Nawa } \\
\text { Sanga sesuai Arah } \\
\text { Mata Angin }\end{array}$ & $\begin{array}{l}\text { Markerless } \\
\text { AR }\end{array}$ \\
\hline $\begin{array}{l}\text { P. Nikko, W. } \\
\text { Hafidha, and } \\
\text { E. Sudarmilah } \\
\text { (2014) }\end{array}$ & $\begin{array}{l}\text { Kimia } \\
\text { (Tabel } \\
\text { Periodik) }\end{array}$ & $\begin{array}{l}\text { Menggambarkan unsur } \\
\text { kimia pada golongan A } \\
\text { yang direpresentasikan } \\
\text { dalam object } 3 \\
\text { Dimensi dilengkapi } \\
\text { dengan contoh soal } \\
\text { serta tabel periodik. }\end{array}$ & $\begin{array}{l}\text { AR } \\
\text { Latihan } \\
\text { Soal }\end{array}$ \\
\hline $\begin{array}{l}\text { Aditya et al. } \\
\text { (2016) }\end{array}$ & $\begin{array}{l}\text { Sejarah } \\
\text { (Museum } \\
\text { Gedung } \\
\text { Karangasem } \\
\text { dan Gedung } \\
\text { Tabanan) }\end{array}$ & $\begin{array}{l}\text { Menampilkan objek } \\
\text { visualisasi benda- } \\
\text { benda yang ada di } \\
\text { museum. }\end{array}$ & $\begin{array}{l}\text { Pemodelan } \\
\text { Objek } \\
\text { Museum }\end{array}$ \\
\hline $\begin{array}{l}\text { D. E. } \\
\text { Nurcahyo and } \\
\text { B. S. Hantono } \\
(2015)\end{array}$ & $\begin{array}{l}\text { Kedokteran } \\
\text { (Anatomi } \\
\text { Tubuh) }\end{array}$ & $\begin{array}{l}\text { Menampilkan organ } \\
\text { tubuh manusia secara } \\
\text { live }\end{array}$ & $\begin{array}{l}\text { Pemodelan } \\
\text { organ } \\
\text { tubuh } \\
\text { secara live }\end{array}$ \\
\hline $\begin{array}{l}\text { Mauludin et al. } \\
\text { (2017) }\end{array}$ & $\begin{array}{l}\text { Kimia } \\
\text { (Tabel } \\
\text { Periodik) }\end{array}$ & $\begin{array}{l}\text { Menampilkan huruf } \\
\text { 3D dari unsur Kimia } \\
\text { Gologan A beserta } \\
\text { Informasi, tabel SPU } \\
\text { Kimia dan latihan soal. }\end{array}$ & $\begin{array}{l}\text { AR } \\
\text { Latihan } \\
\text { Soal }\end{array}$ \\
\hline $\begin{array}{l}\text { A. Subagyo et } \\
\text { al. } \\
(2015)\end{array}$ & $\begin{array}{l}\text { Matematika } \\
\text { (Bangun } \\
\text { Ruang) }\end{array}$ & $\begin{array}{l}\text { Menampilkan } \\
\text { bangun objek } \\
\text { ruang dari marker. }\end{array}$ & $\begin{array}{l}\text { Marker } \\
\text { Based }\end{array}$ \\
\hline $\begin{array}{l}\text { F. Bakri, D. } \\
\text { Ambarwulan, } \\
\text { and D. } \\
\text { Muliyati(2018) }\end{array}$ & $\begin{array}{l}\text { Fisika } \\
\text { (Gelombang } \\
\text { Bunyi dan } \\
\text { Optik }\end{array}$ & $\begin{array}{l}\text { menampilkan AR 3D } \\
\text { gelombang bunyi dan } \\
\text { optic }\end{array}$ & $\begin{array}{l}\text { Video } \\
\text { Object }\end{array}$ \\
\hline $\begin{array}{l}\text { Ahmadi et } \\
\text { al. (2017) }\end{array}$ & $\begin{array}{l}\text { Agama } \\
\text { Islam } \\
\text { (Shalat) }\end{array}$ & $\begin{array}{l}\text { Menampilkan gerakan- } \\
\text { gerakan shalat. }\end{array}$ & $\begin{array}{l}\text { Animasi } \\
\text { 3D }\end{array}$ \\
\hline $\begin{array}{l}\text { S. Hamzah } \\
\text { and D. } \\
\text { Kurniadi } \\
(2019)\end{array}$ & $\begin{array}{l}\text { Komputer } \\
\text { (Perangkat } \\
\text { Keras) }\end{array}$ & $\begin{array}{l}\text { Menampilkan } \\
\text { visualisasi perangkat } \\
\text { keras computer. }\end{array}$ & $\begin{array}{l}\text { Pemodelan } \\
\text { Objek } \\
\text { Perangkat } \\
\text { Keras } \\
\text { computer. }\end{array}$ \\
\hline
\end{tabular}

Tabel 2 menampilkan ringkasan berbagai bidang dimana teknologi AR diadaptasi dan diterapkan untuk proses belajar mengajar. Mayoritas studi menunjukkan hasil umpan balik positif dari para peserta mengenai aplikasi AR yang sedang diselidiki [20][16]. Sebagai kesimpulan penelitian lebih lanjut mengenai kolaborasi AR dalam proses belajar mengajar harus dilanjutkan karena manfaatnya tidak saja diperoleh oleh siswa, namun juga tenaga pengajar. Dengan bantuan AR, pengajaran mata pelajaran yang memerlukan visualisasi dapat ditingkatan dan dibandingan dengan pembelajaran tanpa menggunakan AR atau metode pembelajaran konvensional. Seperti yang diringkas pada Tabel III Augmented Reality telah di gunakan sebagai media pembelajaran di berbagai bidang untuk berbagai macam tujuan dan dikolaborasikan serta di elaborasikan dalam berbagai macam fitur. Pada bidang astronomi, telah diimplementasikan bagaimana siswa bisa mempelajari tata surya berserta mekanisme dan prosesproses yang terjadi di dalamnya secara visual, berbagai 
jenis planet, bintang, satelit dan berbagai macam instrument didalamnya divisualisasikan dalam kemasan Augmented Reality [27]. Dalam hal religi pun Augmented Reality dapat digunakan sebagai media edukasi, sebagaimana dalam penelitian yang telah dilakukan untuk merepresentasikan konsep Agama Hindu yaitu Dewata Nawa Sanga, penelitian ini mengkolaborasikan sensor gyroskop serta teknologi accelerometer pada smartphone untuk menunjukkan posisi dari arah mata angin yang melambangkan Dewa-Dewa Agama Hindu yang memiliki maknanya tersendiri dan merupakan pedoman dasar dari masyarakat yang beragama Hindu. Penelitian ini tentunya membuktikan bahwasannya Augmented Reality merupakan teknologi yang bersifat adaptif dan dapat berkolaborasi dengan berbagai macam teknologi lainnya [26]. Begitu juga pada media pembelajaran Agama Islam juga telah menerapkan teknologi Augmented Reality yang dapat memvisualisasian gerakan gerakan shalat yang akan memudahkan pengguna dalam membayangkan gerakan shalat yang tepat dan tidak keliru apabila hanya mempelajari dengan arahan kata-kata saja [28]. Augmented Reality juga telah digunakan sebagai media pembelajaran mata pelajaran kimia, dimana siswa dapat mempelajari tabel periodik menggunakan teknologi ini. Augmented Reality dalam penelitian ini memvisualisasikan unsur jumua pada golongan A yang dilengkapi dengan contoh soal [19]. Selanjutnya Augmented Reality juga telah diterapkan untuk mempelajari mata pelajaran sejarah, dimana siswa bisa mempelajari isi dari museum dengan menggunakan teknologi ini secara virtual [17] . Pun juga seperti yang telah dijelaskan sebelumnya, Augmted Reality telah dimanfaatkan dalam media pembelajaran Biologi yaitu edukasi untuk mempelajari organ dalam tubuh manusia yang memanfaatkan media animasi sebagai visualisasi proses yang terjadi dalam bagian tubuh [29]. Bagi anak-anak, mempelajari bangun ruang memang sedikit sulit. Namun setelah di representasikan ke dalam bentuk Augmented Reality, cukup mudah untuk mereka untuk mengenali jenis-jenis bangun ruang yang ada seperti kubus, balok, prisma, limas, bola dan lain sebagainya. Sehingga dengan mengetahui ilustrasi dari bentuk bangun ruang tersebut akan memudahkan mereka dalam menghitung volume dari bangun ruang tersebut dan membedakan rumus-rumus dari bagaimana mencari volume dari bangun ruang tersebut [30]. Augmented Reality juga telah di kembangkan sebagai media edukasi untuk mempelajari mata pelajaran fisika, bahkan gelombang suara yang notabene sulit untuk di visualisasikan. Penelitian yang telah dilakukan dapat memvisualisaikan gelombang bunyi dan optik dimana dalam pengaplikasiannya mengkombinasikan teknologi Augmented Reality dengan perangkat lunak penampil video [31]. Terakhir, dalam ringkasan penelitian Augmented Reality juga menjelaskan bahwasannya telah dibuat media edukasi perangkat keras dari mata pelajaran Ilmu Komputer, dimana di zaman yang semakin maju ini tentunya pengetahuan akan perangkat keras terutama

I Wayan Andis Indrawan : Augmented Reality Sebagai Media... komputer sangat penting, dimana bagian-bagian dari komputer yang dalam pengaplikasiannya akan selalu di upgrade ke tingkatan yang lebih baik disetiap tahunnya. Minimal dengan mengetahui nama part dan visualisasinya, sehingga tiap-tiap siswa dapat mengetahui dan mengembangkan ilmunya jika ingin meningkatkan kapasistas dari komputer mereka. Dengan begitu pemerataan pengetahuan mengenai perangkat komputer dimasa depan dapat dicapai dan akan teknologi akan lebih cepat berkembang [32].

\section{HASIL DAN PEMBAHASAN}

Dari hasil review serta analisis mengenai Augmented Reality yang telah dibahas dirangkum poin-poin yang merupakan kelebihan Augmented Reality yang menguatkan bahwasannya teknologi ini dapat dikatakan baik serta cocok untuk dimaanfaatkan sebagai media Pendidikan Interaktif dalam bentuk ide-ide atau solusi terlepas dari batasan kemampuan yang terkandung dalam Augmented Reality itu sendiri [27]. Mekanisme variatif yang ditawarkan Augmented reality menjadikannya teknologi fleksibel yang cocok dengan banyak jenis bidang. Konsep Augmented Reality untuk merekonstruksi media Pendidikan menjadi digital cukup simpel dan linier.

\section{A. Implementasi Augmented Reality dalam Pendidikan Formal}

Augmented Reality sejatinya telah melahirkan produkproduk Pendidikan dengan kaedah-kaedah yang sesuai dengan bidang ilmu yang di rekonstruksi. Teknologi ini mampu menggaet minat para calon penggunanya yang dikuatkan dalam beberapa penelitian terakhir. Penerapan Augmented Reality ke dalam dunia Pendidikan akan menjadi solusi bagi para tenaga pendidik untuk membantu mereka memberikan pengetahuan kepada para siswa. Produk-produk Augmented Reality yang dibuat untuk suatu bidang ilmu spesifik bisa diimplementasikan untuk dimasukkan kedalam kurikulum Pendidikan formal Indonesia mulai dari Sekolah Dasar, Sekolah Menengah Pertama, Sekolah Menengah Atas dan juga Perguruan Tinggi. Mekanisme pembelajaran yang dapat digunakan untuk pembelajaran menggunakan Augmented Reality ini bisa dibagi menjadi dua, yaitu pembelajaran mandiri di rumah (sudy from home) di masa Pandemic Covid-19 dan pembelajaran kolektif diruang kelas apabila pembelajaran tatap muka sudah dapat dilaksanakan.

\section{B. Pemerataan Infrastruktur}

Peranan pemerintah sangat dibutuhkan dalam kolaborasi pengembangan digitalisasi dunia Pendidikan khususnya untuk penerapan pembelajaran menggunakan teknologi Augmented Reality ini. Negara Indonesia yang cukup luas tentunya membutuhkan atensi khusus terutama untuk daerah yang belum terjamah infrastruktur pendukung seperti smartphone atau Laptop sebagai media yang mensupport penggunaan Teknologi Augmented Reality. p-ISSN:1693 - 2951; e-ISSN: 2503-2372

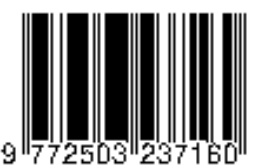


Permasalahan ini bisa diakomodir dengan mengalihkan sedikit pendanaan pemerintah untuk realisasi pengadaan smartphone atau Laptop dengan spesifikasi yang cukup untuk dipinjamkan ke siswa yang tidak memiliki smartphone. Sistem pinjam smartphone dan Laptop ini akan berjalan linier dengan kebutuhan pembelajaran daring menggunakan teleconference yang saat ini sudah diimplementasikan. Kedepan aset-aset ini akan sangat berguna apalagi di zaman teknologi seperti saat ini. Pemenuhan kebutuhan infrastruktur ini tentu akan memberikan banyak dampak positif bagi dunia Pendidikan di Indonesia.

\section{Augmented Reality untuk Siswa Berkebutuhan Khusus}

Teknologi Augmented Reality sekolah berkebutuhan khusus (bisu, tuli, autis, cacat fisik dan lain sebagainya) patut menjadi perhatian karena juga turut terdampak pandemi. Skena ini tentunya juga akan sangat terbantu dengan usulan penerapan pembelajaran dengan memanfaatkan teknologi Augmented Reality. Namun tentunya Sekolah berkebutuhan khusus dalam penerapannya membutuhkan peranan ekstra dari orang tua dan guru terutama untuk mengajarkan cara penggunaan dan penerapannya.

\section{Virtual Lab dengan Augmented Reality}

Metode pembelajaran didalam kelas pada masa Pandemi Covid-19 bisa diakomodir dengan video conference, begitu juga dengan laboratorium. Laboratorium dalam proses digitalisasi membutuhkan teknologi yang mampu memuat entitas-entitas laboratorium dan pengimplementasiannya secara virtual tanpa mengurangi tujuan utama didalamnya. Salah satu teknologi yang memungkinkan untluk merealisasikan ide ini adalah Augmented Reality, dimana mekanismenya bisa dimuat dalam bentuk Virtual Laboratorium. Virtual Laboratorium dapat di intepretasikan sebagai pengganti pembelajaran siswa di laboratorium. Laboratorium virtual atau V-Lab di masa Pandemi Covid-19 seperti saat ini akan memegang peranan penting dalam mengimplementasikan kegiatan praktikum. V-Lab dalam bentuk Augmented Reality bisa digunakan sebagai sarana eksperimen berbagai macam bidang mata pelajaran, dapat digunakan berinteraksi, dapat digunakan untuk simulasi dan dapat digunakan untuk menggantikan praktek di laboratorium. Fungsi-fungsi Augmented Reality dapat dikombinasikan dan sangat mendukung proses virtualisasi laboratorium ini.

\section{E. Augmented Reality untuk PAUD dan TK}

Masa belajar anak-anak yang di era ini dimulai dari Pendidikan Anak Usia Dini atau PAUD serta Taman Kanak-Kanak atau TK turut terdampak Pandemi Covid-19. Pembelajaran anak-anak yang biasa belajar dan bermain bersama disekolah harus ditiadakan sementara secara tatap muka. Proses belajar dan bermain dari anak-anak ini sementara dialihkan dengan video conference atau daring. Tentu hal ini akan menjadi membosankan bagi anak-anak harus belajar layaknya orang dewasa di depan Laptop berjam-jam untuk menerima materi pembelajaran. Selain akan terkendala permasalahan infrastruktur baik device ataupun koneksi internet, orang tua akan menjadi lebih repot untuk mengakomodir kebutuhan dari buah hatinya. Augmented Reality dapat menjadi solusi sebagai media Pendidikan interaktif untuk pembelajaran sekaligus bermain dengan teknologi ini. Augmented Reality bisa digunakan sebagai media pengenalan binatang, tumbuhan, ataupun materi pembelajaran lainnya yang tentunya lebih menarik karena berbentuk visualisasi animasi. Konsep dari Augmented Reality ini sangat sederhana, dari keseluruhan ide atau solusi yang dipaparkan diatas, mekanisme variasi pengembangan Augmented Reality adalah sama. Hanya saja yang membedakan adalah variable-variabel yang akan digunakan di dalamnya. Berikut konsep dari Augmented Reality dalam kaitannya dengan pengembangan Media Pendidikan Interaktif.

Flowchart diatas adalah konsep yang bisa diaktualisasikan dalam rekayasa perangkat lunak dalam pembuatan media pendidikan interaktif augmented reality. Proses awal yang dilalui adalah pengambilan gambar menggunakan kamera. Kamera yang digunakan tidak tertutup hanya dengan smartphone android saja, bisa juga dengan media lain seperti webcam, kamera poket, serta kamera jenis lainnya yang dapat digunakan input dengan platform seperti computer, laptop dan lain-lain. Fungsi kamera ini terbagi menjadi 2 yaitu untuk menampilkan display dari dunia nyata serta fungsi lainnya adalah untuk menangkap trigger yang menjadi pemicu tampilnya realitas tertambah. Adapun objek tambahan berupa realitas tertambah ini merupakan intisari dari ilmu yang terkandung dari bidang pelajaran yang dibuat dalam berbagai bentuk seperti objek 3D, animasi, suara ataupun video yang

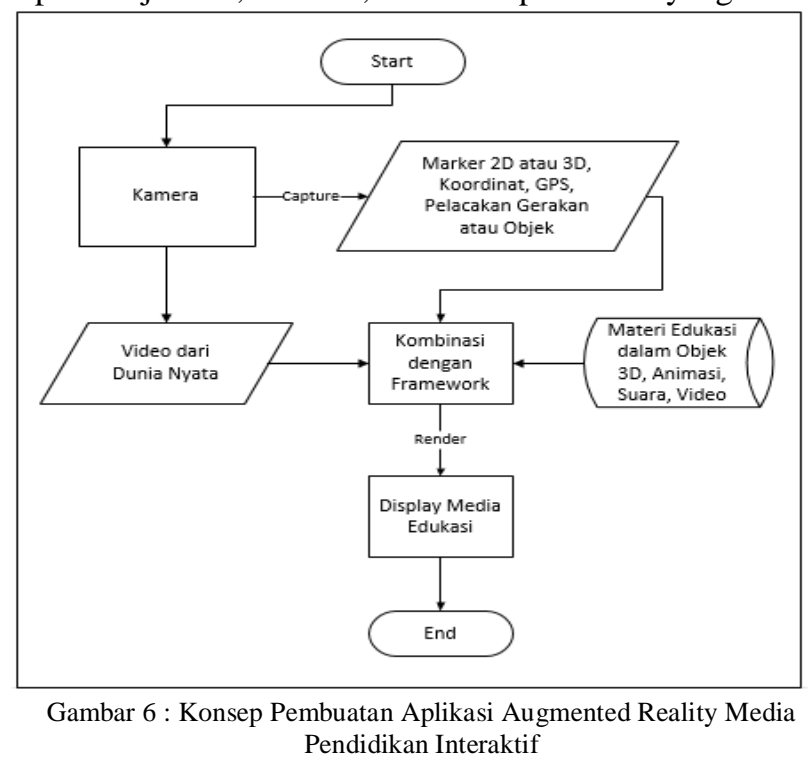

tersimpan dalam database. Ketiga aspek tersebut kemudian di kombinasikan menggunakan framework sesuai dengan kebutuhan aplikasi.Ada banyak framework yang bisa digunakan antara lain Vuforia, ARKit, Ionic, Cordova, Dive Durovis dan lain sebagainya. Setelah dikombinasikan menggunakan framework, aplikasi akan merender video serta material sehingga menampilkan display kombinasi dari dunia nyata dan realitas tertambah berupa Media 
Pendidikan Interakstif untuk meningkatkan kapasitas interaksi antara aplikasi dan siswa.

Oleh karena itu, kedepan di bidang pendidikan harus menyelidiki potensi AR untuk meningkatkan metode pengajaran di sistem pendidikan negara dan untuk meningkatkan efisiensi proses belajar mengajar. Seperti halnya memaksimalkan potensi untuk mengembangkan markerless augmented reality sehingga mengurangi tingkat gagal deteksi marker. Selain itu pengembangan Augmented Reality kini mulai merambah kes metode lain seperti motion detection, face tracking [34], bahkan GPS Based [15] untuk meningkatkan kapasitas interaksi antara aplikasi dan siswa. Media ini cukup eksklusif dan interaktif dan masih bisa dikembangkan dari segi konten, dengan harapan dapat menjadi media belajar yang menyenangkan dan dapat dipelajari dari rumah sebagai bentuk realisasi study from home dalam Pandemi Covid-19 yang sedang berlangsung saat ini karena mendukung elemen-elemen protap Kesehatan seperti menjaga jarak, tidak berkumpul dan tidak bepergian.

\section{KeSIMPULAN}

Kesimpulan dari penelitian ini adalah Augmented Reality dalam dunia Pendidikan belum diimplementasikan serta diterapkan sebagai media pendukung Pendidikan interaktif di berbagai jenjang mulai dari Sekolah Dasar, Sekolah Menengah Pertama, Sekolah Menengah Atas dan Perguruan Tinggi, pun juga pada Pendidikan lain seperti Sekolah Berkebutuhan Khusus (Difabel), Taman KanakKanak serta PAUD. Teknologi ini sebenarnya sudah memunculkan ide-ide untuk melahirkan media-media edukasi mengenai berbagai bidang ilmu, namun belum ada instansi Pendidikan yang menerapkannya sebagai media wajib yang berfungsi menjadi sarana pembelajaran lebihlebih di Masa Pandemi Covid 19 ini. Augmented Reality adalah salah satu skena digitalisasi pendidikan pada penerapan pembelajaran interaktif yang dapat menjadi solusi permasalahan ini. Teknologi ini memiliki potensi untuk mendukung pembelajaran study from home maupun pembelajaran dikelas. Penerapan Augmented Reality ke dalam dunia Pendidikan akan menjadi solusi bagi para tenaga pendidik untuk membantu mereka memberikan pengetahuan kepada para siswa selain video conference. Produk-produk Augmented Reality yang dibuat untuk suatu bidang ilmu spesifik bisa diimplementasikan untuk dimasukkan kedalam kurikulum Pendidikan formal Indonesia mulai dari Sekolah Dasar, Sekolah Menengah Pertama, Sekolah Menengah Atas dan juga Perguruan Tinggi, pun juga untuk Sekolah Berkebutuhan Khusus (Difabel), PAUD serta Taman Kanak-Kanak. Mekanisme pembelajaran yang dapat digunakan untuk pembelajaran menggunakan Augmented Reality ini diimplementasikan dengan metode pembelajaran mandiri dalam bentuk Virtual Lab selama belajar di rumah (study from home). Namun realisasi ini membutuhkan atensi khusus terutama untuk daerah di Indonesia yang belum terjamah infrastruktur pendukung seperti smartphone atau Laptop sebagai media

I Wayan Andis Indrawan : Augmented Reality Sebagai Media... yang mensupport penggunaan Teknologi Augmented Reality. Media ini cukup eksklusif dan interaktif dan masih bisa dikembangkan dari segi konten baik animasi 3D, interaksi dengan pengguna, video, efek suara dan lain sebagainya. Harapan kedepan teknologi ini bisa menjadi media pembelajaran yang menyenangkan dan dapat dipelajari dari rumah sebagai bentuk realisasi study from home dalam Pandemi Covid-19 yang sedang berlangsung saat ini karena mendukung elemen-elemen protap Kesehatan seperti menjaga jarak, tidak berkumpul dan tidak bepergian.

\section{REFERENSI}

[1] S. Verguet and D. T. Jamison, Health Policy Analysis: Applications of Extended Cost-Effectiveness Analysis Methodology in Disease Control Priorities, Third Edition. 2017.

[2] S. Koç, G. Yilmaz, and Y. Kabak, "The clinical guidelines usage towards the diagnosis and treatment of H1N1," in 2010 5th International Symposium on Health Informatics and Bioinformatics, 2010, pp. 67-71.

[3] P. M. A. Sloot, A. V Boukhanovsky, W. Keulen, and C. A. Boucher, "A grid-based HIV expert system," in CCGrid 2005. IEEE International Symposium on Cluster Computing and the Grid, 2005., 2005, vol. 1, pp. 471-486 Vol. 1.

[4] Yuliana, "Corona virus diseases (Covid -19); Sebuah tinjauan literatur," Wellness Heal. Mag., vol. 2, no. 1, pp. 187-192, 2020.

[5] Z. Zahrotunnimah, "Langkah Taktis Pemerintah Daerah Dalam Pencegahan Penyebaran Virus Corona Covid-19 di Indonesia," SALAM J. Sos. dan Budaya Syar-i, vol. 7, no. 3, 2020.

[6] A. Purwanto, U. P. Harapan, and S. Ekploratif, "Studi Eksplorasi Dampak Work From Home (WFH) Terhadap Kinerja Guru Selama Pandemi Covid-19," Edupsycounts J., vol. 2, pp. 92-100, 2020.

[7] F. Z. Adami and C. Budihartanti, "Penerapan Teknologi Augmented Reality pada Media Pembelajaran Sistem Pencernaan Berbasis Android," J. Tek. Komput. Amik BSI, vol. 2, no. 1, pp. 122-131, 2016.

[8] A. A. K. Oka Sudana, I. G. A. A. Mas Aristamy, and N. K. Ayu Wirdiani, "Augmented Reality Application of Sign Language for Deaf People in Android Based on Smartphone," Int. J. Softw. Eng. Its Appl., vol. 10, no. 8, p. 140, 2016.

[9] A. Azzam, R. Faisal, and M. P, "PEMBANGUNAN FLASH CARD BERBASIS AUGMENTED REALITY UNTUK MENUNJANG PEMBELAJARAN PADA ANAK PRA SEKOLAH,” Teknoin, vol. 21, Dec. 2015.

[10] N. M. Maslin, P. Consultant, and S. S. Ltd, "Impact of Modern Technology," HF Commun., vol. 3, pp. 33-35, 2010.

[11] S.-W. Jang, J. Ko, H. J. Lee, and Y. S. Kim, "A Study on Tracking and Augmentation in Mobile AR for e-Leisure," $J$. Mob. Inf. Syst., vol. 2018, p. 4265352, 2018.

[12] R. Novianti, "Pengaruh Lingkungan Belajar Terhadap Tingkat Konsentrasi Belajar Siswa Pada Mata Pelajaran Akidah Akhlak Di Man 2 Palembang," Encycl. Surv. Res. Methods, vol. 1, no. 1, 2019.

[13] P. Suardani, Y. Divayana, and K. O. Saputra, "Analisis Komentar Hasil Belajar Siswa Menggunakan Opinion Summarization," Maj. Ilm. Teknol. Elektro, vol. 18, no. 1, p. 61, 2019.

[14] G. Ahmad et al., "Analisis Kemampuan Kemampuan Penalaran Dan Self Confidence Siswa Sma Dalam Materi Peluang," $J$. Educ. P, vol. 1, no. 1, pp. 14-21, 2018.

[15] P. Chiu, P. Tseng, and K. Feng, "Interactive Mobile Augmented Reality System for Image and Hand Motion Tracking," IEEE Trans. Veh. Technol., vol. 67, no. 10, pp. 9995-10009, 2018.

[16] A. Burhanudin, "Pengembangan Media Pembelajaran Augmented Reality Pada Mata Pelajaran Dasar Elektronika di SMK Hamong Putera 2 Pakem," Pendidik. Tek. Mekatronika, vol. 7, no. 3, pp. 266-274, 2017.

p-ISSN:1693 - 2951; e-ISSN: $2503-2372$

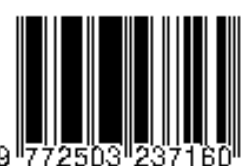


[17] I. G. Aditya Nugraha, I. K. G. Darma Putra, and I. M. Sukarsa, "Rancang Bangun Aplikasi Augmented Reality Museum Bali Berbasis Android Studi Kasus Gedung Karangasem dan Gedung Tabanan," J. Lontar Komput., vol. 7, no. 2, pp. 93-103, 2016.

[18] C. Althea, S. Lahallo, A. A. K. Agung, C. Wiranatha, and I. G. M. Arya, "Media Pembelajaran Molymod Senyawa Hidrokarbon Teknologi Augmented Reality Berbasis Android," J. Ilm. Merpati (Menara Penelit. Akad. Teknol. Informasi), vol. 4, no. 2, pp. 123-134, 2016.

[19] P. Nikko, W. Hafidha, and E. Sudarmilah, "Augmented Reality Sistem Periodik Unsur Kimia Sebagai Media Pembelajaran Bagi Siswa Tingkat SMA Berbasis Android Mobile," KomuniTi, vol. VI, no. 2, pp. 122-131, 2014.

[20] M. F. Ningsih, "Pengaruh Media Pembelajaran Augmented Reality Terhadap Hasil Belajar Siswa Pada Konsep Gelombang," 2015.

[21] G. Yudha, P. Pangestu, N. Made, I. Marini, N. Kadek, and D. Rusjayanthi, "Aplikasi Web Augmented Reality Villa," vol. 5, no. 1, pp. 29-40, 2017.

[22] I. K. Yostab Mariyantoni, N. Padma, I. G. M. Darmawiguna, and M. W. Antara Kesiman, "Augmented Reality Book Pengenalan Perangkat Gamelan Bali," Janapati, vol. 3, no. 1, pp. 21-28, 2014.

[23] R. Mauludin, A. S. Sukamto, and H. Muhardi, "Penerapan Augmented Reality Sebagai Media Pembelajaran Sistem Pencernaan pada Manusia dalam Mata Pelajaran Biologi," J. Edukasi dan Penelit. Inform., vol. 3, no. 2, p. 117, 2017.

[24] I. D. G. Wahya Dhiyatmika, I. K. G. Darma Putra, and N. M. I. Marini Mandenni, "Aplikasi Augmented Reality Magic Book Pengenalan Binatang untuk Siswa TK," J. Lontar Komput., vol. 6, no. 2, p. 121, 2016.

[25] K. Susanna Dwi Yulianti, "Perancangan Aplikasi Augmented Reality Pembelajaran Tata Surya Dengan Menggunakan Marker Based Tracking," J. Inform. Univ. Pamulang, vol. 3, no. 1, pp. 33-38, 2018.

[26] I. W. A. Indrawan, I. P. A. Bayupati, and D. P. S. Putri, "Aplikasi Markerless Augmented Reality Dewata Nawa Sanga Berbasis Android," J. Ilm. Merpati (Menara Penelit. Akad. Teknol. Informasi), vol. 5, no. 2, p. 34, 2017.

[27] C. A. Sugianto, "Aplikasi Edukasi Tata Surya menggunakan Augmented Reality Berbasis Mobile," Informatics Res. Dev., 2018.

[28] R. A. Ahmadi, J. Adler, and S. L. Ginting, "Teknologi Augmented Reality sebagai Media Pembelajaran Gerakan Shalat," Pros. Semin. Nas. Komput. dan Inform., vol. 2017, pp. 179-186, 2017.

[29] D. E. Nurcahyo and B. S. Hantono, "Pemanfaatan Augmented Reality Dalam Dunia Pendidikan Untuk Mempelajari Anatomi Tubuh Manusia Berbasis Android," Jurnal, vol. 2015, no. Sentika, pp. 193-198, 2015.

[30] A. Subagyo, T. Listyorini, and A. Susanto, "Pengenalan Rumus Bangun Ruang Matematika Berbasis Augmented Reality," Pros. SNATIF, vol. 2, no. 2, pp. 29-32, 2015.

[31] F. Bakri, D. Ambarwulan, and D. Muliyati, "Pengembangan Buku Pembelajaran Yang Dilengkapi Augmented Reality Pada Pokok Bahasan Gelombang Bunyi Dan Optik," Gravity J. Ilm. Penelit. dan Pembelajaran Fis., vol. 4, no. 2, pp. 46-56, 2018.

[32] S. Hamzah and D. Kurniadi, "Pengembangan Media Pembelajaran Perangkat Keras Jaringan Berbasis Augmented Reality Pada Platform Android," Vokasional Tek. Elektron. dan Inform., vol. 7, no. 3, pp. 1-12, 2019.

[33] P. Sommerauer and O. Müller, “Augmented reality for teaching and learning - A literature review on theoretical and empirical foundations," 26th Eur. Conf. Inf. Syst. Beyond Digit. - Facet. Socio-Technical Chang. ECIS 2018, no. July, 2018.

[34] M. Nurhadi, "Rancang Bangun Aplikasi Augmented Reality Berbasis Face Tracking untuk mendeteksi Wajah Peserta Wisuda," Processor, vol. 13, no. 1, pp. 1189-1199, 2018. 